\title{
Land Titling and Power Building in the Three Regimes of Ethiopia: The Last Empire, the First Republic, and the Second Republic
}

\author{
Abebe Amare ${ }^{1}$ \\ Wasihun Gebreegziabher ${ }^{2}$ \\ Gifawosen Markos ${ }^{3}$
}

\begin{abstract}
Land is not a mere physical resource in Ethiopia; rather it has a strong tie with social values and political power. Apparently, scholars in this particular area have largely focued on the residual effects of land dispossessions and the harsh incursions into the communal sanctities. Moreover, they paid an enormous attention to the effects of land grabbing on the economic, social and human rights of individuals. However, this article argues that less attention has been given to the role of land titlting in buiding the power of political elites in Ethiopia. In order to explore this, the article attempted to anlyze the three regimes in Ethiopia- the Emperial, Derg, and EPRDF- and their land entitlment strategies as a means of power making and legitimization of the establishments. The artilce, thus, concludes that there have been a strong connection between land and power in the three regimes of Ethiopia and it maintains that land tilting strategies have been extensively used for the political interests and power grabbing objectives of the regimes.
\end{abstract}

Keywords: Ethiopia, Land Policy, Land titling, Land Tenure, Power building

DOI: $10.7176 / \mathrm{JCSD} / 55-02$

Publication date: January $31^{\text {st }} 2020$

\section{Introduction}

Land deal, land grabbing, land rush, and land enclosures are the common terminologies popular among scholars to explain the massive anti-ecological transfer of the global south land resources to the global economic scavengers (GeislerandMakki, 2011). However, wide the conceptual battlefield is among diverse scholars that point how the terms are a misnomer and the social and economic ecologies are far-reaching, land transfer is being facilitated through flexible but destructive land entitlement procedures (Berry, 2002; and Borras and Franco, 2010). At the dawn of 2008, the global economic crisis and the consequent food and energy insecurity mined the global rush for the financial and material foundation which found fertile ground in the global south. This facilitated what Arrighi (1994) has called "systematic cycles of accumulation".

In Ethiopia, the dynamic process of land transfer that violated the human, economic, and social right of the local settlers has been rationalized through some basic alternating assumptions that transplanted land rights from one group to another. On the one hand, land entitlement transplantations have been justified on account of facilitating agricultural development through the attraction of foreign investors as was done by the Ethiopian government since the end of 2009 (Rahmato, 2011). Besides, land entitlement has also been subject global media attention and analysis in relation with the human right violation and extra-constitutional procedures that tend to favor the land scavengers in the low land frontiers of Ethiopia (Berry, 2002).

Land has consumed a large tract of scholarly literature by sociologists, economists, land experts, and historians who invested a special focus on the residual effects of land dispossessions, and harsh incursions into the communal sanctities. Scholars also paid attention to the effects of land grabbing on the economic, social and human rights of individuals. Makki (2011 and 2012) finds that land enclosures in Ethiopia are expressed along with the parallel processes of state formation. In a similar vein, Rahmat (2011) noted that land and state in Ethiopia are inseparable in that the land has been a central element in determining the relationship between Church, monarchies, and peasants. On the other hand, Lavers (2012), Bezabih et al (2011), Adal (2000), Adal (2001),Deininger and Jin (2006), Deininger et al. (2009) noted how the state has been the major mediating actor in transferring land for reasons of agricultural investment and tenure insecurity problems. Nonetheless, an extensive and much deeper look at land titling and power building is not sufficiently addressed. Particularly, some of the basic mysteries behind land transfers, preferential land provisions, generous land transfers, and denial of land entitlements have to be found out in the process of land titling. Land titling has wide space and time dimensions along with global dynamics. Thus, it is essential to invest some scientific investigations in this regard.

The basic purpose of this paper is not to explore the economic effects of land titling to foreign affiliates or

\footnotetext{
${ }^{1}$ Department of Governance and Development Studies, Wolkite University

${ }^{2}$ Department of Civic and Ethical Studies, Wolkite University

${ }^{3}$ Department of Governance and Development Studies, Wolkite University
} 
domestic patrimonial groups. Nor is the paper an investigation of the basic assertions made by scholars regarding the values and virtues of privatizing or communalizing land in Ethiopia. Rather, the study focuses on understanding how land titling has been a subject of contradictory claims and policy initiatives to build power for the political elites in Ethiopia. In due course, special regard is paid to explore how altering government arguments, elite's legitimacy concerns, peasants' or communities' land virtues, and large scale land transfers have been maintained to preserve the power grabbing objectives. Consequently, the shifts and contradictions to the legal and juridical contradictions of land titling are studied to a certain extent.

Therefore, an extensive study of how land has served as a means of power making and legitimization feeds a fresh insight to establish a more solid framework of rearranging the relationship between land and power. This leads the process of recapping and remaking land as a rationalizing force of developing an organic social metamorphism and political transformations. Thus, land entitlement as a shaping stone of land market, efficient land development, food security, and agricultural transformation has to be studied to re-sketch the political wavelengths.

\section{Theorizing Land Titling and Power Building}

The transition from the old mythical, and to some extent, genetically-justified sacred political oligarchies into the modern secular republic is understood to have been facilitated by the central role of land titling. The period up until the late Eighteenth century was typically characterized by the monopoly of land through sacred but random scripts, land titling has been carried out with the traditional religious principles uneasily mixed with political crowning. There is a complex intersection between land titling and power building. African countries in the postindependence period kept on implementing the rules of land possession and consumption on account of building power. There has been intensive competition between the political power holders and the people who should determine and decide land entitlements (Barrey, 2002; Rahmato, 2008). As a result of this, it is said that the dynamics of political power in Africa begins and ends with land.

Though the arguments that refute the existence of a peasant-landlord relationship in the African soil exist, contemporary political and sociological arguments stress the otherwise. Szymond Chodak in the "Birth of an African Peasantry" (1971) and Guy Hunter in "Modernizing Peasant Societies: a comparative study in Asia and Africa" (1969) noted the non-existence of peasant-land lord relationship and thus ignore how the political elites try to take control of land property entitlements and build their political power muscles. On the contrary, scholars of recent chronological lineage explain the ties of political power and land entitlements. In this regard, John Cohen's "Ethiopia: a survey on the existence of a feudal peasantry" (1974), Donald Levine's Wax and Gold: tradition and innovation in Ethiopian culture (1965), Frederick Simmons' Northwest Ethiopia: peoples and economy (1960), George Lipsky et al.'s"A Pagan-Hebraick Peasantry of Ethiopia” (1969), Simon Messing's "The highland plateau Amhara of Ethiopia" (1957), and Dan Bauer's "Land, leadership and legitimacy among the IndertaTigray of Ethiopia" (1972) provide a conceptual understanding of how peasants and their land in Ethiopia have been instruments for power building.

The major economic, demographic, and environmental factors that determine the distribution, market value, and productive potential of land have been secondary and derivative of political interests and power grabbing objectives in Africa (Rahmato, 2008). Land development has been a reflex of the general political ontology that is enclosed and patrimonial in nature. Therefore, the ability of a small circle of oligarchies controlling the general population has been executed through the control of land entitlements, acquired from and denied by the political elites. As a result, land has become a center of controversies and contradictions by the political elites. On the one hand, the struggle for power has been justified by the virtues of redistributing land, improving wellbeing, transforming livelihood (Cohen, 1974). On the other hand, power preservation has been made on the violation of the principles of equal distribution of land, the possession of land, and the control over land. Kroeber (1948) further explained that political power emerges from land-related entitlements in the following manners: the economic infrastructure of dominant elites is derived through taxation and land tributes, and political power emerges from the politician's office.

Regarding the species of feudalism and peasantry in which land entitlement is the entry to property and power accumulation, scholars noted that the Ethiopian reality resembles the conceptual taxonomies of Bloch and Beattie (1961). Frederick C. Gamst (1970) in "Peasantries and Elites without Urbanism: the Civilization of Ethiopia" finds out how Ethiopian politics is highly conjoined with the land entitlement and the corresponding feudalistic elements. In this regard, he finds the existence of the political dependence between the vassal and the landlord, survival of a weakened state, and the derivative nature of monarchical power from land property elements (ibid.). Therefore, it is in such a complex set of interactions between the political elites and the peasants that power generation and preservation takes place in Ethiopia. Consequently, the broad texture of land entitlement and the attendant power building becomes intelligible in the light of such conceptual clarifications. 
How land titling has been a rationalizing instrument among Ethiopian political oligarchies, old and contemporary alike?

The absolutist nature of the Ethiopian empires emerges from and is justified through land values. Land served as the most rationalizing realm, shaping the interaction of the people and the elites in Ethiopia. However, the procedures and dynamics are as fragile and confusing as the interests of the elites are. In some circumstances, land and its productive values have been heavily influenced by the policy intentions and personal whims of politicians. On the other extreme, land has also been serving as the most powerful reason to struggle for powersharing and conservation projects (Rahmato, 2008). The basic premise behind government policy conclusions, shifts, and contradictions is that land entitlements determine the legitimacy of the government's power (Makki, 2014). In this regard, land titling has assumed a privileged but confusing article in the various legal documents of the country (Lavers, 2012).

\section{Last Empire: The Emperor's Quasi-Feudalistic Land Programs}

The emperor applied different principles that govern its relationship with the existing tribal leaders. In this regard, the emperor controlled two third or three fourths of the communal lands, then divided the remaining one among the chief leaders. In this way, the emperor tactically avoided any form of stiff resistance and maximized power centralization and legitimization, making the regional lords custodians of land grants by himself (Lavers, 2012). Imperial land grants were made on the basis of power contending potential of the grantee. As a result, nobles, emperor agents, various favored nobilities were granted land. In this way, the emperor was, apart from maximizing economic benefits through taxation, able to get the legitimacy of dangerous power contenders and/or imprison the potential of regional lords.

During the reign of the emperor, there was some basic contrasts between the northern and southern ecological hemispheres in relation to the land entitlements. This geographical and social divide provided a lasting cultural and political significance which was rationalized with the basic assumptions of civilizing and modernizing the classic society (Makki, 2012). In the northern hemisphere, rather than dismantling the genealogical land entitlement tradition called rist ${ }^{l}$, the imperial species super-imposed $g u l^{2} t$ system that provided gult holders the right of taxation and political monopoly over ristegna communities (Rahmao,1985, Crummey, 2000, and Donham, 1986). Through gult system, the gult holders were entitled to have control over rist holders and to extract the surplus which was sent to the treasury port of the imperial palace residents. Gult holders' power extends from this. They provided juridical, security, and administrative services based on the instructions of the emperor (Markakis and Ayele, 1976). The limited significance of the northern material foundation for the political power scripture of the imperial family turned attention towards the southern and southwestern ecologies which experienced different historical makeup (Makki, 2012).

In the Southern and SoutheWestern part of the country, the most common type of land entitlement system employed under the imperial regime was the private tenure system. Addording to Cohen and Weintraub (1973), the private entitlements were formed when the emperor take the possession of land conquered by its armies and granted the overwhelming majotity of it to a wide range of people and institutions. Land grants were made to the army memebers, administrators who came from the north as a civil servants of the emperor, peasants moving south because of land and environmental pressure in the north, local or native tribes that did not resist the conquest, indeginous village and clan chiefs to gain their support, a host of central and provincial elites close to the monarch and church officials and institutions to facilitate the expansion of the Coptic religion. Besides, those lands in these areas unoccupied by the aforementioned people and institutions were also considered to be state property and it was distributed to men of influence and power in the state apparatus (Adal, 2002). However, lands under private tenures were not private in the strict capitalist sense, rather all land under the private entitlement was originally state property and the state could take away whenever needed (Dessalegn, 1984 cited in Adal, 2002).

The brief period of Italian occupation (1935 to 1941) had also its own effect on traditional land ownership in Ethiopia (Chala, 2016). According to Chala, the most victims of Italian invasion were not poor peasants, but nobility and land owners. By appropriating gult and rist lands Italians distributed it to their loyal servants. As a result, the existing land entitlement system was disrupted. With this instance the nobility and other land owners who had been intimately associated with the emperor and ruling class families became victims of the Italian land grabbing strategy. By doing so, the Italians gravely weakened land owning nobility and in some parts of Ethiopia, they totally eliminated it (ibid.)

In the post-liberation period-1941, land as the material foundation of the emperor's power received some

${ }^{1}$ Rist is the right to claim a share of land based on kinship to a historical ancestor held in common with other rist holders (see Cohen, John and Weintraub, Dov, 1975, Land and Peasants in Imperial Ethiopia: The Social Background of a Revolution for the detail)

${ }^{2}$ Gult rights over land were land entitlements given to members of the ruling elite as a reward to loyal service to their lord and to religious institutions as endowments (see Hoben, Allan, 1973, Land Tenure among the Amhara of Ethiopia: The Dynamics of Cognisant Descent, Chicago: The University of Chicago for the detail) 
changes. The changes further eroded the material basis of the gult holders and made them less important. The 1944 new taxation system introduced by the emperor reduced the role of gult holders and systematically centralized the collection of resources from land (Markakis and Ayele, 1976). Accordingly, the Ministry of Finance robbed the gultegna of their land entitlement and land titling acquired a modern form of processing (Rahmato, 1985).

\section{The Second Republic: Derg's Disguised Land Capitalism}

The 1975 land reform of the Derg has been considered by many as a radical measure that has abolished the tenant-landlord relations in Ethiopia (Adal, 2002). Proclaiming itself as the group that maintains the country's sovereignty in the brink of political turmoil, Derg (a group of military juntas) made a reform on land tenure, which was the factor behind the downfall of the emperor. That measure brought the whole peasants except the landlords to euphoria. In a dramatic fashion, Derg assumed an escalating legitimacy from the rural inhabitants which made the majority parcel of the population (Crummey, 2000). Nevertheless, the stated objectives of egalitarianism, productivity, and efficiency of smallholder agriculture did not materialize as the land tenure policy was not a program of "Land to the Tiller" as loudly echoed by the students. It was rather a program of land to the politicians, a program of building the material foundation of power, with a teleological impact of shrinking the power of those outside the political circle (Donham, 1986).

The land tenure policy measure was nothing but a replacement of the old characters with new characters. Land to the tiller policy with its superficial nature simplified the existing old mix of state, church, and landlordism and brought it under the armpit of the military junta. In the beginning, the proclamations appear innocent. The government showed a good face to bring a uniform and egalitarian distribution of land rights (Makki, 2012). The proclamation reads as follows:

As of the effective date of this Proclamation, all rural lands shall be the collective property of the Ethiopian people (Sub Article, 1). No person or business organization or any other organization shall hold rural land in private ownership (Sub Article, 2). No person may by sale, exchange, succession, mortgage, antichresis, lease or otherwise transfer his holding to another; provided that upon the death of the holder the wife or husband or minor children of the deceased or where these are not present, any child of the deceased who has attained majority, shall have the right to use the land (Article, 5) (PMAC, 1975).

The rural land proclamation provided a monopoly of land titling to the Derg administrative groups, destroying the communal sanctities. This avoided any form of the lowest form of land administration (Clapham, 1988). Rather, land became the custody of the socialist orientation of the Derg officials who designed socialism and land tenure policy to appeal to the domestic and international legitimacy (Donham, 1998). Ignoring the repetitive advice of the Chinese and Soviet friends, the Derg officials rushed, in the absence of an organized bureaucracy, to look after land property through peasant associations and Zemecha programs (Keller, 2008). Thus, it engaged in the program of pasteurizing the power of titling land. This was an exhibition of the Derg's intention of building the material/property estate of its power, which has been a tradition in Ethiopia for so long. When the initial programs of land titling became ineffective, the military junta injected a series of other proclamations designed to bring the means of production under its control (Rahmato, 2011). Producer cooperatives were destined to fulfill the political thrusts of the government. They emerged to implement the land titling objectives of the military junta (Rahmato, 1984).

After the first Zemecha, more and more property owning peasants began to work at arm's length from the government (Crummey, 2000). Colonel Mengistu designated this as "rampant individualism and Petty bourgeoisie" (Keller, 2008). This created a threat of losing power grip over the material foundation of its power. The Derg, as a result, begun rearrangement procedures: stipulation of proclamation and establishment of organizations (Rahmato, 2009). The proclamation helped to legalize and reclaim the power of the Derg by providing a ground to control property owning peasants. This was done through the deployment of various government agents in various places. Keller (2008) explains as follows:

The proclamation set up the Central Planning Supreme Council under the direction of PMG Chairman Mengistu. The organization consisted of a congress with representatives from all parts of the country, an executive committee, a secretariat, a provincial development campaign and, planning office, plus similar offices at the regional and district levels. Delegates to the congress and employees in the other institutions represented all major interests in society. The permanent staff of the NRDC was around 1,000 by the end of 1981, and included seven or eight Soviet advisers.57 importantly, however, the new organization appeared top-heavy with Derg personnel, and bureaucrats far outnumbered workers and representatives from other mass organizations (Keller, 2008).

Nevertheless, the residual effect of the proclamation was dependent on the power building mission of the Derg officials. The land policy measures, rather than changing the structure of hierarchy in favor of the peasants, were taken as a deceptive provincial flavor for the majority of the peasants and the building of the legitimacy of 
the government. Ruthless intrusions into the livelihood base of the pastoralist communities brought a tragic obstruction to the achievement of the objectives of "Land to the Tiller" calls. Core-periphery relationships were architected in a new form but with similar draconian impacts (Markakis, 2008; and Makki, 2012).

The "Public Ownership of Rural Land Proclamation" nationalized all rural land and set out to redistribute it to its tillers and to organize farmers in cooperatives, thereby abolishing exploitative landlord-tenant relations so pertinent under the imperial regime. However many shortcomings of the land reform are also cited, though it seems that they could be related more to the general agrarian policies of the Derg than the land reform per se. many scholars argue that the land tenure system since then has badly affected the country's agricultural production and sustainable land use in the lowland part of the country (see Adal 2002, Ambaye, 2012). The problems associated with Derge's land reforms include: land fragmentation as a result of repeated redistribution, repeated redistribution gave rise to and exacerbated tenure insecurity among peasant households.

\section{The Second Republic: EPRDF's Capitalistic Land Enclosure for Power Enclosure}

The EPRDF regime, immediately upon coming to power, began to re-knit the diverse Ethiopian communities under the overarching sanctities of the polyglot constitution. Harboring a large pack of debate, the constitution declared land as the sacred property of the state and nations and nationalities which are the Alfa Omega of the regime. The 1995 Ethiopian Constitution romantically entitles land as the property of the state as follows and entitles the people with land that cannot be arbitrarily robbed.

The right to ownership of rural and urban land, as well as of all natural resources, is exclusively vested in the State, and in the peoples of Ethiopia. Land is a common property of the Nations, Nationalities and Peoples of Ethiopia and shall not be subject to sale or to other means of exchange (Sub-article, 3). Ethiopian peasants have the right to obtain land without payment and the protection against eviction from their possession. The implementation of this provision shall be specified by law (Sub-article, 40 (FDRE Constitution).

\section{Spatial Based Irregular Land Entitlement Treatments Under the EPRDF Regime}

A contrast of the central/core part of the country and the peripheral areas reveals a tragic story. The government has been employing different processes of power building procedures in the two places. The basic principle employed in the core areas, owing to historical, and cultural contexts, was the formation of hierarchical, dominant-subordinate land ownership rights (Jemma, 2001; and Clapham, 2018). On the contrary, the last frontiers of peripheral areas hosted the theorem of deforesting communal land titles and replacing them with government introduced juridical modern titling (Makki, 2012).

In the core areas, land registration and titling processes were started, with good performance in the first two-three years in terms of governance, representation, and women empowerment (Deninger and Ali, 2008). Gradually, however, the land registration process brought no significant impacts upon the lives of the peasant as predicted by economists (Chinigo, 2015). In the absence of absolute land ownership rights, the peasants were systematically convinced to take the land registration for granted, and give their blessing to the government. Their land ownership became submissive to the government's heavy hands as the land registration was introduced without the provision of adequate tenure security (Crewett and Korf 2008). In this way, the government brought the death of one of the powerful inputs of capital generation- incentive and security. Peasants, in the absence of genuine government efforts, were advised to attend the process that facilitates the power preserving the intention of the government (Lefort 2012, 681; and Holden and Tefera 2008, 32). Peasants allowed enjoying the short term euphoria of land registration while the government was building its muscle. Hammond calls such processes as a "Strategies of Invisibilization" (2008).

In the peripheral areas, the government began to play both comedy and tragedy characters. It held various meetings, concerts, and consultations with the local community. Nevertheless, the local communities were forced to become inhabitants of artificial social structures that led them to suffer from landlessness, powerlessness, hunger, and displacement (Deininger, Ali, and Alemu, 2011). Various programs were introduced to slowly drag the pastoralist settlers into their death camps, such as involuntary villagization and forced resettlement (Bezabih et al., 2011). This is grossly contradictory to the basic principles laid out in the constitution and the rural land proclamation which altogether affirm the right of peasants to have land (Holden and Tefera, 2008).

\section{Coercive Legitimization Process by Weakening Delegitimizing Groups}

In a systematic and silent mode, the very existence of the rural community has been made dependent on the provision of legitimacy to the ruling party. In this regard, land has been employed as a powerful weapon to make the rural communities who side with opposition parties to drop their opposition and accept the power of the ruling government (Hammond, 2008).

An exchange between the government and the rural community facilitated social and economic 
rearrangement of the rural inhabitants. The steps are silent. First, the rural communities are made to depend on the government for property rights which made the foundation of livelihood of the majority of Ethiopians. Therefore, these peasants are forced to have subsistence mode of livelihood which compels them to be vulnerable to famine, drought, and lack of productivity. Then, these people are encouraged to give their political allegiance and affiliation to the ruling government in exchange for food aid and non-transforming risk management programs (Deininger, Ali, and Alemu, 2011).

\section{Legal Structures: Biasness and Openness}

In the 1990s, the EPRDF government has been showing favor and strong affection towards peasants, expressed in terms of small holder-focused agricultural policy. Land policies, agricultural policies, and package programs were all peasant-friendly (Rahmato, 2011). The 1995 constitution and the Rural Land Proclamation provided shelter for the government's power building objectives. It goes like this: Land is the common property of the Ethiopian nations, nationalities, and peoples (FDRE, 1995, Article 40(3)); and a smallholder whose land is expropriated for public activities is compensated in three forms, property situating on the land, permanent improvement made on the land and displacement compensation (FDRE, Article 40(8); Federal Rural Land Proclamation, Article 7 and 8). Nonetheless, something is still mysterious. What about the taking of the land? The taking of land entitlement by the peasants is the most powerful resource left unanswered. In addressing this concern, Tura (2018) in his study claimed that laws that justify land titling for the community are flawed and incomplete which is exploited by the government to maximize its power port.

Gradually, however, the government began to manipulate the controversial land policy stated in the constitution. A cyclical process of integrating the smallholder farmers into the global commercial market has changed the fate of the peasants for the worst. Dispossession through displacement and differentiation began to take place in various parts of the country in spite of strong global and domestic critics (Makki, 2012). The neoimperial negotiation process with the global investors has exposed the peasants to various forms of expropriation, displacement, dispossession, and famine (Hagman and Abbink, 2012). The political motives behind such programs are tragic and self-serving one.

In the post-2005 election, arguments against the position of the regime were treated with imprisonment and suppression. The arguments were taken as delegitimizing attempts that further deteriorate the legitimacy of the government both in the eyes of the donor countries and domestic peasants (Rahmato, 2011; Makki, 2012). As a result, the government has taken a patrimonial assumption towards the rural populace in that the peasants are to be protected by the state power and policy, which is indirectly a mechanism to establish the rural base of power. Land redistribution under the overwhelming control of the state has strong historical backgrounds. Land as a means of power accession has become a means of remaining in power by enjoying a quantitative advantage over experts and opposition forces.

The EPRDF's land policy, which brought the state at the top of the pyramid of land control, made the peasants depend on the will and whim of the state officials. Partly, this provided the government a demographic advantage, in terms of legitimacy, over any form of power contenders and made it the Alfa Omega guarantor of access to livelihood for the majority of Ethiopians. The government carefully takes advantage of the interception between land property and election campaigns. In many circumstances, when election is coming, or when its legitimacy is deteriorating, the government began to quickly craft land-focused policy initiatives (Hammoond, 2008; Hagman and Abbink, 2012; andLavers, 2012) which are for the most part taken as virtues and benign attempts of the government.

The government was massively intervening in the livelihood base of pastoralists, last frontiers, with the presumption that these landsare empty waiting for as Makki (2012) called it" the redemptive role of the government". The basic driving motive behind this is not economical neither public responsibility but rather a program of remaking international image so as to remain in power,untouched and unchallenged. This is what we can call legitimizing the illegitimate discourse of developing empty lands.

\section{Commercialization of Agriculture: For whom?}

The EPRDF government repeatedly announced its focus to transform the agricultural sector by introducing commercialization of small holder farmers (Rahmato, 2008; Zenawi, 2006). However, the government began to engage in large scale land grabbing from the last frontiers on the reasons of commercialization of land in the country (Lavers, 2012; Makki, 2011). Against the human right, property right, and survival of the local settlers, the government brought high business profile investors both domestic and foreign ones to do whatever they want on the land of these local settlers (Deininger and Byerlee, 2011). Gambella, Somali, Afar, and Omo river settlers faced this harsh reality. These large scale investors have, in one way or another, strong link with the governing officials. While the government provides security service, special protection, convincing processes, and settlement of local disputes either through deceptive dialogues or coercive mechanisms, the large scale commercial investors have been executing their contract (Tamrat, 2010). The consequence of which has been 
fueling the power vessel of the regime. Anyone outside the enclosed structure has, nevertheless, been brutally pushed to the edge.

The tables below demonstrate how land transfer was aggressively and massively conducted in the various core and peripheral zones of Ethiopia.

Table 1 Large scale land transfers in Ethiopia

\begin{tabular}{|c|c|c|c|c|c|c|c|}
\hline Investor Name/ & Nationality & Region & $\begin{array}{l}\text { Investment } \\
\text { Type }\end{array}$ & $\begin{array}{c}\text { Land } \\
\text { Transfer }\end{array}$ & $\begin{array}{c}\text { Capital } \\
\text { Registered }\end{array}$ & Land Rent & Agreement \\
\hline Company Name & & & & $\begin{array}{c}\text { Area of } \\
\text { Ha }\end{array}$ & $\begin{array}{l}\text { (Mill } \\
\text { Birr) }\end{array}$ & $\begin{array}{l}\text { Per Year } \\
\text { (Birr) }\end{array}$ & $\begin{array}{l}\text { Signed } \\
\text { Date }\end{array}$ \\
\hline Adama & Ethiopian & SNNPR & Cotton & 18516 & 323 & $2,925,528.00$ & $12 / 18 / 02$ \\
\hline $\begin{array}{l}\text { Daniel } \\
\text { Agri.Dev.Enterprise }\end{array}$ & Diaspora & SNNPR & Cotton, grains & 5000 & 65 & $790,426.60$ & $1 / 11 / 02$ \\
\hline $\begin{array}{l}\text { Lucci Agricultural } \\
\text { Development PLC }\end{array}$ & Ethiopian & SNNPR & Cotton & 4003 & 83 & $632,474.00$ & $3 / 30 / 02$ \\
\hline Mela Agri. Dev. & Ethiopian & SNNPR & Cotton & 5000 & 42 & $790,000.00$ & $3 / 10 / 02$ \\
\hline Rahwa & Ethiopian & SNNPR & Cotton, grains & 3000 & 14 & $474,000.00$ & $9 / 7 / 02$ \\
\hline Reta & Diaspora & SNNPR & Cotton, grains & 2137 & 13 & $337,740.00$ & $1 / 11 / 02$ \\
\hline Ruchi & Indian & Gambella & Soy beans & 25000 & 1451 & $2,775,000.00$ & $7 / 2 / 02$ \\
\hline TsegayeDemoze & Diaspora & SNNPR & Cotton, sesame, & 1000 & 9 & $158,000.00$ & $5 / 17 / 02$ \\
\hline White Field & Indian & SNNPR & Cotton & 10000 & 32 & $1,580,000.00$ & $11 / 25 / 02$ \\
\hline $\mathrm{BHO}$ & Indian & Gambella & $\begin{array}{l}\text { Edible oil } \\
\text { crops }\end{array}$ & 27000 & 918 & $2,997,000.00$ & $9 / 3 / 02$ \\
\hline Sannati & Indian & Gambella & Rice & 10000 & 160 & $1,580,000.00$ & $1 / 24 / 03$ \\
\hline Verdanta & Indian & Gambella & Tea & 3012 & 631 & $334,332.00$ & $8 / 13 / 02$ \\
\hline Shmporji & Indian & B/Gumuz & $\begin{array}{l}\text { Pongamia } \\
\text { (Biofuel) }\end{array}$ & 50000 & 984 & $7,170,000.00$ & $6 / 22 / 02$ \\
\hline Keystone & Diaspora & B/Gumuz & $\begin{array}{l}\text { Horticultural, } \\
\text { crops }\end{array}$ & 431 & 66 & $307,134.91$ & $4 / 26 / 02$ \\
\hline CLC (Spentex) & Indian & $\begin{array}{l}\text { B/Gumuz\& } \\
\text { Amara }\end{array}$ & Cotton & 25000 & 1177 & $5,548,750.05$ & $4 / 17 / 02$ \\
\hline Access Capital & Ethiopian & B/Gumuz & Sesame beans & 5000 & 61 & $3,288,750.00$ & $2 / 1 / 03$ \\
\hline $\begin{array}{l}\text { KaruturiAgro } \\
\text { Products PLC }\end{array}$ & Indian & Gambella & $\begin{array}{l}\text { Palm cereals, } \\
\text { rice, sugar } \\
\text { cane }\end{array}$ & 100000 & 2110 & $2,000,000.00$ & $2 / 26 / 03$ \\
\hline Saudi Star & Saudi & Gambella & Rice & 10000 & 37640 & $3,000,000.00$ & $2 / 22 / 03$ \\
\hline $\begin{array}{l}\text { HuanaDafengyuan } \\
\text { Agriculture }\end{array}$ & China & Gambella & Sugar cane & 25000 & 2973 & $3,950,000.00$ & $11 / 5 / 02$ \\
\hline Kehedam Trading & Diaspora & B/Gumuz & Oil crops & 3000 & 13 & $1 / 013,400.00$ & $3 / 28 / 03$ \\
\hline Dr. Tamie Hadgu & Diaspora & SNNPR & Cotton, seeds & 5000 & 74 & $790,000.00$ & $4 / 9 / 03$ \\
\hline Bruhoye & Ethiopian & B/Gumuz & $\begin{array}{l}\text { Cotton, soy } \\
\text { beans }\end{array}$ & 5000 & 60 & $960,000.00$ & $4 / 8 / 03$ \\
\hline $\begin{array}{l}\text { ASKY Agricultural } \\
\text { Development }\end{array}$ & Ethiopian & B/Gumuz & Cotton & 3000 & 60 & $333,000.00$ & $7 / 13 / 03$ \\
\hline $\begin{array}{l}\text { Tracon Trading Pvt. } \\
\text { Ltd/Co. }\end{array}$ & Ethiopian & B/Gumuz & Cotton & 5000 & 61 & $1,972,500.00$ & $7 / 13 / 03$ \\
\hline
\end{tabular}

Source: Ethiopian Agricultural Portal: Ministry of Agriculture and Rural Development (2011). www.eap.gov.et in Makki (2012). 
Table 2 A partial list of large scale land transfers in Ethiopia (except Gambella).

\begin{tabular}{|c|c|c|c|c|c|}
\hline Investor & $\begin{array}{l}\text { Foreign } \\
\text { domestic }\end{array}$ & $\begin{array}{l}\text { Land } \\
\text { (Hectares) }\end{array}$ & Size & Crops & Location \\
\hline Al Habesh & Pakistan & & 28,000 & Sugar estate & Wollega, Oro \\
\hline Ambassel & Domestic & & 10,000 & Biofuel crops & Metekel, BS \\
\hline B\&D Food & USA & & 18,000 & Sugar estate & Awi, Amhara \\
\hline Chadha Agro & India & & 122,000 & $\begin{array}{l}\text { Sugar, } \\
\text { Biofuel }\end{array}$ & Oromia \\
\hline Djibouti Gov’t & Djibouti & & 3,000 & Food crops & Bale, Oromia \\
\hline Dubai World & Dubai & & 5,000 & Tea & Illubabor, Oro \\
\hline E. Africa Agric & Domestic & & 6,500 & Food crops & Pawe, BeniShangul \\
\hline Emami Biotech & India & & 80,000 & Biofuel crops & Oromia \\
\hline FinoteSelaam & Domestic & & 5,000 & Sesame & Guba, Benishangul \\
\hline Flora EcoPower & German & & 13,000 & Biofuel crops & E. Harage, Oro \\
\hline Fri El Green & Italy & & 30,000 & Biofuel crops & Omo Valley, SNNP \\
\hline Global Energy & Israel & & 10,000 & Biofuel & Wollaita, SNNP \\
\hline IDC Invest & Danish & & 15,000 & Biofuel & Assossa, BS \\
\hline Kanan D Hills & India & & 10,000 & Tea & SNNP \\
\hline Karuturi & India & & 11,000 & Rice, Biofuel & Bako, Oromia \\
\hline P. Morrell & USA & & 10,000 & Wheat & Bale, Oromia \\
\hline N. Bank Egypt & Egypt & & 20,000 & Food crops & Afar \\
\hline OmoSheleko & Domestic & & 5,500 & Cotton, palm & SNNP \\
\hline PetroPalm & German & & 50,000 & Biofuel & $\begin{array}{l}\text { Rayitu, } \\
\text { Oromia }\end{array}$ \\
\hline SHAMPORJI & India & & 50,000 & Biofuel & BeniShangul \\
\hline Spentex & India & & 25,000 & Cotton & BeniShangul \\
\hline Sun Biofuels & UK & & 5,000 & Biofuel & Wollaita, SNNP \\
\hline Sun Bio (NBC) & UK & & 80,000 & Biofuel & Metekel, B.S \\
\hline Sunrise Indust & India & & 15,000 & Food & Oromia \\
\hline Tomaisin & Israel & & 10,000 & Food crops & Oromia \\
\hline Vatic & India & & 20,000 & Biofuel & Borena, Oromia \\
\hline United Farm Bus & Domestic & & 3,000 & Food crops & Bako, Oromia \\
\hline Yehudi Hayun & Israel & & 10,000 & Biofuel & Oromia \\
\hline
\end{tabular}

Source: Findings from field visits, MOARD, MELCA Mahiber 2008, local press reports, InRahmato (2011).

\section{Conclusion}

Modern land tenure regimes in Ethiopia fall into three far-reaching time periods. Before 1975, land tenure was based on a feudal system where land was controlled in the hands of absentee proprietors, tenure rights were greatly insecure, and arbitrary evictions took place. Following the upheaval of the imperial regime in 1974, the Marxist-oriented government (the Derge) moved possession of all rural land to the state for the supply of use rights to the peasants through the local peasant associations. The further transfer of this land right was highly limited due to the transfer through sales, lease, exchange, or mortgage was banned, and inheritance was strictly restricted. Tenure security was more weakened by the peasant associations' and other authorities' ability to redistribute land. The popular students' movement with the quest of "land to the tiller" was hijacked by the socialist Derge's peasants association. The government that took power in 1991 following the fall of the Derge while committed to a free-market philosophy - has made little practical change to farmers' land rights, which are still considered inadequate.

As far as the modern Ethiopian land tenure (land titling) is concerned, much of the power over the land resource and sole ownership is vested in the hands of the regimes. Land grabbing, land acquisition, expropriation without proper compensation explains the recent history of land policy in Ethiopia. The ordinary citizens are still not possessors of the land though they give a high value to it.

Overall, there have been less progressive policy changes over the years within the context of the statecontrolled tenure system. Only a few changes of land tenure policy including halting or slowing land redistribution or adjustment; broadening land access through permitting bequeathing land and limited transaction inland market, setting minimum farm size and certifying land rights were advocated. However, such policy action has been largely reactive and tentative (USAID/Ethiopia, 2004). The constitutionality of some of these expanded rights is also questionable since the 1995 constitution. For example, the constitution still prohibits any transfer of land other than through state-mandated institutions. The current policies continue to restrict ways of accessing land, emphasize on administrative-based land allocation, show weakness in provision and protection of 
land rights, restrict the private development of land resources, and limit indigenous institutions to economize on scarce land resources.

Public policy has an important role in the future, but it needs an informed and a balanced view that emphasizes on searching for equitable but efficient and sustainable tenure arrangements that are mediated through the market place. As detailed in (Ambaye, 2012), major policy changes are necessary that expand ways to acquire land and facilitate efficiency-enhancing land transfers, enhance secured control in land rights, permit tradable land rights and reduce transaction costs, improve management of common resources and joint action, eliminate political and administrative restrictions on access to land, and develop land and other factor markets in tandem.

Overall, throughout the last half a century and more, the regimes which ruled the country have made use of land as an important instrument to build and consolidate their power. This practice is still persistent as the incumbent government constitutionally decreed land as the property of the state and manupulates it in the process of strengthening its might.

\section{The way forward}

Concerns with the insecurity of tenure are foremost related to the constancy of tenure and restricted applications of land rights (Ambaye, 2012,Adal, 2002, USAID/Ethiopia, 2004). The thrust of public policy is hence to create stable and secured tenure systems that permit farmers to fully exercise rights in land at low enforcement and transaction costs. Public responses so far involve bequeathing use rights to land, halting or slowing redistribution of land to create a climate of stability, titling use rights in some regional states, and accepting, in principle, compensation for added value in land in case of government expropriation.

Policy deliberation should be participatory and must consult all the stakeholders. Moreover, informed public policy is critical to minimize costly policy error. Public policy is likely to be correct and effective when it is guided by empirical and analytical policy researches. Policy prescription requires asking the right research question, diagnosing the underlying source of the problem, matching the right prescription to the cause of the problem, weighting the costs and benefits associated with policy choice, and assessing the institutional and human capacity to implement, monitor and evaluate performance.

There are important policy prescriptions in the current federal and regional laws that are based on thin empirical evidence such as setting minimum farm size, choice of land allocation criteria, valuation of land and compensation. The debate on land policy has to also move out of the realm of political ideology and be guided by empirical based approach that finds equitable but efficient tenure system that is mediated through the market place. The challenge ahead is to strengthen these markets to pursue the aforementioned goals.

\section{Acknowledgement}

The authors are greateful for staffs of College of Scoial Science and Humanities, Wolkite University for their constructive comments.

\section{Declaration of intereset statement}

The authors declare that there is no any conflict of interest in this manscript.

\section{References}

Adal, Y. (2000). PreliminaryassessmentoftheimpactsofthePost-Derglandpolicyon agricultural production: a case study of land redistribution in two communities in north-western Ethiopia. In: Workneh, N., Legesse, D., Abebe, H.G., Solomon, B. (Eds.), Institutions for Rural Development. Proceedings of the 4th Annual Conference of Agricultural Economics Society of Ethiopia. Addis Ababa, 23-24 November 1999, pp. 173190.

Adal,Y.(2001).SomequeriesaboutthedebateonlandtenureinEthiopia.In:Demeke,M.,Woldehanna,T.(Eds.),Explaini ngGrowthandDevelopmentinEthiopia.Proceedings of the Tenth Annual Conference on the Ethiopian Economy. November 2-5, 2000. Ethiopian Economic Association (EEA), Addis Ababa.

Adal, Y. (2002). Review of Landholding Systems and Policies in Ethiopia under the Different Regimes. EEA/Ethiopian Economic Policy Research Institute, Working Paper No 5/2002.

Ambaye, D. W. (2012). Land Rights in Ethiopia: Ownership, equity, and liberty in land use rights Land Rights in Ethiopia : ownership, equity, and liberty in land use rights, (May), 6-10.

USAID/Ethiopia. (2004). Ethiopia Land Policy and Administration Assessment, (4).

Arrighi, G. 1994. The long twentieth century. London: Verso.

Berry, S. (2002). Debating the Land Question in Africa. Comparative Studies in Society and History, Vol. 44, No. 4, pp. 638-668. http://www.jstor.org/stable/3879518.

Bezabih, M., Kohlin, G.andMannberg, A. (2011). Trust, tenure insecurity, and land certification in rural Ethiopia. The Journal of Socio-economics. The Journal of Socio-Economics 40 833-843. 
Bloch, Feudal Society, passim, and Beattie, 'Bunyoro' (1961). pp. 25. London.

Borras, S.M. and J. Franco. 2010. From threat to opportunity? Problems with a 'code of conduct' for landgrabbing. Yale Human Rights and Development Law Journal, 13(1), 507-23.

Chala, T. (2016). Analysis of politics in the land tenure system: Experience of successive Ethiopian regimes since 1930. African Journal of Political Science and International Relations. Vol. 10(8), pp. 111-118.

Chinigò, D. (2015). The politics of land registration in Ethiopia: territorializing state power in the rural milieu, Review of African Political Economy, 42:144, 174-189, DOI: 10.1080/03056244.2014.928613.

Clapham, C (2018). The Ethiopian developmental state, Third World Quarterly, 39:6, 1151-1165, DOI: 10.1080/01436597.2017.1328982.

Clapham, C. (1988). Transformation and Continuity in Revolutionary Ethiopia. Cambridge: Cambridge University Press.

Crewett, W. and Korf, B. (2008). Reforming Land Tenure. Review of African Political Economy, Vol. 35, No. 116, The Politics of Capital. http://www.jstor.org/stable/20406502.

Crummey, D. (2000). Land and society in the Christian kingdom of Ethiopia: from the thirteenth to twentieth century. Urbana: University of Illinois Press.

Dan Bauer. (1972). Land, leadership and legitimacy among the IndertaTigray of Ethiopia. PhD. Dissertation, University of Rochester.

Deininger, K. and Ali, D.A. (2008). Rural Land Certification in Ethiopia: Process, Initial Impact, and Implications for Other African Countries. World Development Vol. 36, No. 10, pp. 1786-1812. doi:10.1016/j.worlddev.2007.09.012.

Deininger, K., Ali, D.A., Alemu, T.(2009). Impacts of land certification on tenure security, investment, and land markets. EfD Discussion Paper 09-11, a joint publication of the Environment for Development Initiative and Resources for the Future (www.rff.org), Washington, DC.

Deininger, K., D. A. Ali, and T. Alemu. 2011. "Impacts of Land Certification on Tenure Security, Investment, and Land Market Participation.” Land Economics 87 (2): 312-334. E-ISSN 1543-8325.

Deininger, K., Jin, S.(2006). Tenure security and land-related investment: evidence from Ethiopia. European Economic Review 50 (5).

Donald, Levine. (1965). Wax and Gold: tradition and innovation in Ethiopian culture (Chicago).

Donham, D. (1986). Old Abyssinia and the new Ethiopian empire: themes in social history. In: D. Donham and W. James eds. The southern marches of imperial Ethiopia: essay in history and social anthropology. Cambridge: Cambridge University Press.

Frederick Simmons (1960). Northwest Ethiopia: peoples and economy. Madison.

George Lipsky et al's. (1969). A Pagan-Hebraick Peasantry of Ethiopia. New Haven. Giesler, C. and Makki, F. (2014). People, power, and land: New enclosures on a global scale. Rural Sociology. 79(1), pp. 28-33. Doi:10.1111/ruso.12030.

Guy Hunter (1969). Modernizing peasant societies: a comparative study in Asia and Africa.New York and London.

Hagmann, T. andAbbink, J. (2011) Twenty years of revolutionary democratic Ethiopia, 1991 to 2011, Journal of Eastern African Studies, 5:4, 579-595, DOI:10.1080/17531055.2011.642515.

Hammond, L. (2008). Strategies of Invisibilization: How Ethiopia's Resettlement Program me Hides the Poorest of the Poor. Journal of Refugee Studies Vol. 21, No. 4. doi:10.1093/jrs/fen041.

Holden, S.T., Tefera, T., 2008. Early Impacts of Land Registration and Certification on Women in Southern Ethiopia. Summary Report, UN-HABITAT, Shelter Branch, Land Tenure and Property Administration Section. Nairobi.

John, M. Cohen (1974). Ethiopia: A Survey on the existence of a feudal peasantry. The Journal of Modern African Studies. Vol. 12. No. 4, pp.665-672. http://www.jstor.org/stable/159996.

Keller, E.J. (1985). Revolutionary Ethiopia: Ideology, and the limits of state autonomy, The Journal of Commonwealth \&Comparative Politics, 23:2, 112-139, DOI: 10.1080/14662048508447471.

Lavers, T. (2012): Patterns of agrarian transformation in Ethiopia: State-mediated commercialization and the 'land grab', The Journal of Peasant Studies, 39:3-4, 795-822. http://dx.doi.org/10.1080/03066150.2012.660147.

Lefort, R. 2012. 'Free Market Economy, 'Developmental State' and Party-state Hegemony in Ethiopia: The Case of the 'Model Farmers'." Journal of Modern African Studies 50 (4): 681- 706. doi: http://dx.doi.org/10.1017/S0022278X12000389.

Makki, F. (2012) Power and property: commercialization, enclosures, and the transformation of agrarian relations in Ethiopia, The Journal of Peasant Studies, 39:1, 81-104, DOI: 10.1080/03066150.2011.652620.

Makki, F. (2014). Development by Dispossession: Terra Nullius and the Social-Ecology of New Enclosures in Ethiopia. Rural Sociology 79(1), pp. 79-103 DOI: 10.1111/ruso.12033.

Makki, F. and C. Geisler. (2011). Development through dispossession: land grabbing and terra nullius narratives 
in contemporary Ethiopia. Draft paper presented at the International conference on global land grabbing. Institute for development studies, university of Sussex, 8 April.

PMAC. (1975). Proclamation No. 31/75: a proclamation to provide for public ownership of rural lands. Negaritgazeta, 34(26).

Rahmato, D (2011). Land to Investors. Large-Scale Land Transfers in Ethiopia. Forum for Social Studies. ISBN9994450409 (ISBN13: 9789994450404$).$

Rahmato, D.(2008). The Peasant and the State: Studies in Agrarian Change in Ethiopia 1950s - 2000s. Custom books publishing. ISBN-10: 1438266537ISBN-13: 978-1438266534.

Rahmato, D. (2011). Land to investors: large-scale land transfers in Ethiopia. Land Governance for Equitable and Sustainable Development. Available from: http://www.landgovernance. org/system/files/Ethiopia_Rahmato_FSS_0.pdf [accessed 22 August 2011].

Rahmato, D. 2008. The peasant and the state: studies in agrarian change in Ethiopia, 1950s- 2000s. Custom books publishing.

Rahmato, D. (1984). Agrarian Reform in Ethiopia. Uppsala: SIAS.

Simon Messing (1957). The highland plateau Amhara of Ethiopia. PhD. Dissertation, University of Pennsylvania. SzymondChodak (1971). The brth of an African peasantry. Canadian journal of an African studies. Vol.3.

USAID/Ethiopia. (2004). Ethiopia Land Policy and Administration Assessment, (4).

Zenawi, M. 2006. Speech by HE MelesZenawi, Prime Minister of the Federal Democratic Republic of Ethiopia for the Africa Task Force, Brooks World Poverty Institute, Manchester University, UK 3rd to 4th August. 